\title{
Identifying and assessing the potential hydrological function of past artificial forest drainage
}

\author{
Eliza Maher Hasselquist $\mathbb{1}$, William Lidberg, Ryan A. Sponseller, \\ Anneli Ågren, Hjalmar Laudon
}

Received: 21 June 2017/Revised: 6 October 2017 / Accepted: 12 October 2017 / Published online: 2 November 2017

\begin{abstract}
Drainage of forested wetlands for increased timber production has profoundly altered the hydrology and water quality of their downstream waterways. Some ditches need network maintenance (DNM), but potential positive effects on tree productivity must be balanced against environmental impacts. Currently, no clear guidelines exist for DNM that strike this balance. Our study helps begin to prioritise DNM by: (1) quantifying ditches by soil type in the $68 \mathrm{~km}^{2}$ Krycklan Catchment Study in northern Sweden and (2) using upslope catchment area algorithms on new high-resolution digital elevation models to determine their likelihood to drain water. Ditches nearly doubled the size of the stream network $(178-327 \mathrm{~km})$ and $17 \%$ of ditches occurred on welldraining sedimentary soils, presumably making DNM unwarranted. Modelling results suggest that $25-50 \%$ of ditches may never support flow. With new laser scanning technology, simple mapping and modelling methods can locate ditches and model their function, facilitating efforts to balance DNM with environmental impacts.
\end{abstract}

Keywords DEM - Flow accumulation model · Hydrology · LiDAR $\cdot$ Peatland $\cdot$ Terrain-based prediction

\section{INTRODUCTION}

Artificial drainage of forested wetlands and peatlands that increase forest production has profoundly altered the hydrology of North-European landscapes during the twentieth century (Rydin and Jeglum 2009). Near-surface water saturation of soils reduces gas exchange with the atmosphere and thus soil oxygen availability, which in turn impairs the function of plant roots of many species (Sikström and Hökkä 2016). Ditching lowers the ground water level (GWL), increases the depth of the unsaturated zone, and makes conditions more favourable for tree roots. Thus, ditching can increase tree growth if other factors are not limiting, e.g. nutrients (Sikström and Hökkä 2016). Drainage for forestry has been most intense in Europe, affecting at least $20 \%$ of peatland areas (Rydin and Jeglum 2009). The greatest drained areas used for forestry have been in Russia and the Baltic States where over 13.5 million hectares of wetlands have been ditched (Paavilainen and Päivänen 1995); in Canada, similar approaches are being considered (Lavoie et al. 2005).

In the Nordic countries, peatlands have been drained for forestry since the late 1800s or early 1900s (Lundberg 1914). In Sweden, based on the notion that any mire could be turned into a productive forest-and through support from a public works relief programme-state subsidies were granted to private landowners to drain peatlands and wet forests with a peak in ditching during the 1930s (Päivänen and Hånell 2012). During World War II, government funding was reduced, leading to a general decline in the creation of new ditches. During the 1980s, environmental problems associated with ditching gained attention and consultation with the Forestry Board in Sweden was required to create new ditches. Eventually, a permit was required to do this. Now, construction of new forest ditches has virtually ceased due to requirements for Forest Stewardship Council certification (FSC 2010). In Finland, state subsidies also began in the 1930s, stopped during the war, and then peaked between 1950 and 1970 (Päivänen and Hånell 2012). Currently no new peatland areas are being drained in Finland, but new 'complementary ditches' are often dug next to older ditches to maintain drainage (Sikström and Hökkä 2016).

The point of this historical perspective is that most ditches in Sweden were dug before modern mapping 
techniques and predate the living memory of residents. Finland, on the other hand, dug most ditches $30-40$ years later than Sweden and have been actively managing them since (Päivänen and Hånell 2012). Thus, Sweden is left in a situation where many ditches were dug because people were paid to dig them, and these are not always easy to locate on the landscape. Thus, forest managers cannot evaluate if they were planned well in the first place and if or how they should be managed.

Ditches have fundamentally changed the rate, amount, and quality of water as it moves through a catchment, both above and below ground. When wetlands are ditched or shallow drainages are channelised, the flow of water can become several orders of magnitude faster than matrix and macropore flow through soils (Rawls et al. 1993), the dominant flow paths for water in saturated soil. This concentrated flow increases the speed of water and erosive power, and thus more effectively transports water, solutes, and sediment downstream (Doyle and Bernhardt 2011). Furthermore, drainage ditches have altered groundwater flow paths by lowering the water table, increasing bulk density of soils, and decreasing hydraulic conductivities (Silins and Rothwell 1998; Price et al. 2003). In fact, the subsidence of the peat layer is likely the most important factor causing ditches to become shallow (Heikurainen 1957). The resulting change in physical properties of catchments after ditching affect the hydrological functioning of these ecosystems (Silins and Rothwell 1998; Price et al. 2003; Holden et al. 2004), including the patterns and strength of hydrological connections between land and water during different runoff conditions (Jencso and McGlynn 2011). The increased canopy cover of trees and shrubs on drained land also changes groundwater conditions by increasing evapotranspiration (Price et al. 2003; Koivusalo et al. 2008), increasing interception (Price et al. 2003) and reducing groundwater recharge.

In addition to these hydrological changes, forest ditches also influence water quality. For example, ditching may result in 1000-fold increases in suspended sediment concentrations and total yield in peat soils with underlying sand (Painter et al. 1974). Bedload measurements suggest that even after ditches mature, erosion on steeper slopes produces substantial changes in the supply of sediment (Painter et al. 1974; Stenberg et al. 2015). The effects of ditching on stream chemistry are also well documented and include greater concentrations of ammonium and organic $\mathrm{N}$ (Lepistö et al. 1995; Prevost et al. 1999), heavy metals (Holden et al. 2004; Annala et al. 2014), and micronutrients (Åström et al. 2001), as well as elevated pH (Prevost et al. 1999; Åström et al. 2001), and increased water temperature (Prevost et al. 1999). These changes may be the result, at least in part, of lowering of the water table and aerating previously inundated peat soils, which in turn affects microbial processes and decomposition rates (Holden et al. 2004).

To function as intended, drainage ditches may require periodic maintenance (Päivänen and Hånell 2012), but the potential positive effects of maintenance on tree productivity must be weighed against economic and environmental costs. Ditch network maintenance (DNM), or the cleaning out of existing ditches of vegetation, eroded soils, or other debris, can influence water quality similar to that of new forest ditching (Manninen 1998; Joensuu et al. 2002; Koivusalo et al. 2008; Hynninen et al. 2011; Stenberg et al. 2015). Indeed, DNM can also have negative effects on aquatic communities (Hansen et al. 2013). As there is a tradeoff between the negative environmental effects of the ditching and tree productivity, as well as a financial cost of the work, DNM should be applied conservatively. The most recent review of the literature on DNM notes that there is a lack of a robust, standard method for assessing the need for DNM (Sikström and Hökkä 2016). Knowing where and when it is worth the risk of negative environmental effects from DNM will be an important step towards ensuring we can meet timber production goals in a cost-effective way while balancing other ecological and water quality issues.

There are currently no clear guidelines for DNM that are oriented toward striking the balance between forest growth and environmental quality (Sikström and Hökkä 2016). Assessing the functional role of ditches and making decisions about DNM requires a clear understanding of (1) where ditches are located and (2) ditch hydrology, including the timing and duration of seasonal flow. In Sweden, ditches are poorly mapped and the published numbers are only approximations of the length of all ditches constructed (Päivänen and Hånell 2012, Sikström and Hökkä 2016). One advantage of high-resolution LiDAR Digital Elevation Models (DEMs) that are currently being created for whole countries (e.g. Sweden, Finland, Poland, Slovenia), is that they contain information about smallscale features such as ditches. Additionally, upslope catchment area (CA) algorithms and topographic indices based on DEMs have shown great promise for helping us better identify and manage small streams, riparian buffers, wet areas, and groundwater hotspots during forestry operations (Ågren et al. 2014, 2015; Kuglerová et al. 2014; Laudon et al. 2016).

The purpose of this study was to take the first steps towards better understanding how to decide which ditches to maintain. We asked the following questions: (1) did workers dig ditches in all soil types or did they make ditches in soils that are more likely to benefit from draining (i.e. peat)? and (2) do all ditches have the potential to drain water? Our study builds on previous research from the Krycklan Catchment Study (KCS) in northern Sweden on 
the timing and duration of seasonal flow, along with research on flow initiation threshold areas (Ågren et al. 2014, 2015), and uses newly produced high-resolution LiDAR (Light Detection and Ranging)-based DEMs. We hypothesised that there are a large number of ditches on soil types that do not benefit from added drainage, likely because workers were paid to dig ditches regardless of their location (the case of 'thoughtless ditching'). Furthermore, we hypothesised that there are a large number of ditches that, although they may have been dug in soils that could benefit from added drainage, that they do not have sufficient CA to move water regardless of the condition of the ditch (the case of 'poorly-planned ditching').

\section{MATERIALS AND METHODS}

\section{Study area}

Krycklan is a tributary to the Vindel River in northern Sweden, approximately $60 \mathrm{~km}$ north-west of the city of Umeå (Fig. 1; Laudon et al. 2013). The $68 \mathrm{~km}^{2}$ Krycklan Catchment Study (KCS) is relatively typical for the region and has a low relief, varying from 138 to 339 m.a.s.l. (Laudon et al. 2013). The most recent glaciations have resulted in post-glacial isostatic rebound, which has caused land upliftment of approximately $250 \mathrm{~m}$ above the current sea level and has divided the landscape by the former highest coastline (FHC), above which glacial legacy till remains unsorted, and below which larger heterogeneity in the parent material exists from washed till to large deposits of sorted glaciofluvial sediments (Fig. 1; Laudon et al. 2013). The northern part of the KCS is above the FHC, and the southern part below the FHC. The KCS is dominated by secondary forests with a dominance of Scots pine (Pinus sylvestris L.) and Norway spruce (Picea abies L. H. Karst.) with birch (Betula pubescens Ehrh.), alder (Alnus incana (L.) Moench), aspen (Populus tremula L.), and willows (Salix spp.) found in mesic-wet and riparian habitats. Land use is dominated by forestry with clear-cuts representing about $7 \%$ of the catchment. Arable land and built areas represent only about $2 \%$ of the catchment. Although mapped mires only encompass $9 \%$ of the KCS, much of the forested area has been ditched and has overlying peat soil, but it is currently $<50.5 \mathrm{~cm}$ thick. These layers could have been thicker previously, but have compacted with draining, and hence are mapped as 'till soil' in the Swedish system. The mean annual temperature is $1.8^{\circ} \mathrm{C}$ and average precipitation is $614 \mathrm{~mm}$ of which about $40 \%$ falls as snow. The hydrology is snowmelt driven with peak flows occurring during spring flood, usually in May (Laudon et al. 2013). The KCS is an ideal test case for this effort because of the history of hydrological and biogeochemical research, existing field data, and the availability of a highresolution LiDAR-based DEM.

\section{Ditch characterisation}

A LiDAR point cloud with $3.3-10.2$ points $/ \mathrm{m}^{2}$ was used to create a DEM at $0.5 \times 0.5 \mathrm{~m}$ resolution for the KCS. Analytical hillshade models from different angles were used to manually digitalize ditch channels as polylines in ArcMap 10.3. Ditches that were unclear from hillshade layers were verified in the field. We categorised ditches into 'straightened streams' when they overlapped the modelled perennial stream network ( $>10$ ha CA; Åren et al. 2014). We determined the length and percentage of ditches and straightened streams on different soil types within the KCS by grouping soils into four categories based on surveys done by the Geological Survey of Sweden Quaternary Deposits: thin soils and boulder outcrops (Ågren et al. 2014), fluvial sediments, glacial till, and peat (Geological Survey of Sweden Quaternary Deposits map designates peat as $>50.5 \mathrm{~cm}$ ). We then calculated the length and density of ditches and streams for each soil type.

\section{Pre-processing of DEMs and basic description of upslope CA algorithms}

The national DEM from the Swedish Mapping, Cadastral, and Land Registration Authority was used as the basis for the upslope CA algorithms. This DEM is created from a point cloud with a density of $0.5-1$ point $/ \mathrm{m}^{2}$ and has a cell resolution of $2 \times 2 \mathrm{~m}$. All bridges and culverts were manually mapped in the field with a GPS to hydrologically correct the DEM and the mapped ditches were burned into the DEM and given a $1 \mathrm{~m}$ depth (Whitebox GAT 3.3). This manually adjusted DEM was then breached using GoSpatial (Lindsay 2016) in order to solve remaining sinks and create a flow compatible DEM. This new hydrologically corrected DEM was then used as input into flow direction and accumulation models using the Deterministic 8 (D8) algorithm (O'Callaghan and Mark 1984). Because these models are based on DEMs, they assume that subsurface water flowpaths follow surface topography, which is usually the case in forested catchments draining former glaciated landscapes (Rodhe and Seibert 1999; Agren et al. 2014) and is reasonable for other environments as well (Jencso and McGlynn 2011).

By varying the flow initiation threshold in GIS calculations, the stream network during different flow conditions can be mapped (Ågren et al. 2015). Smaller flow initiation thresholds (e.g. 1 ha) predict conditions at high flow, while larger flow initiation thresholds (e.g. 10 ha) predict conditions at low flow (Ågren et al. 2015). We compared two methods of upslope $\mathrm{CA}$ algorithms to determine the 


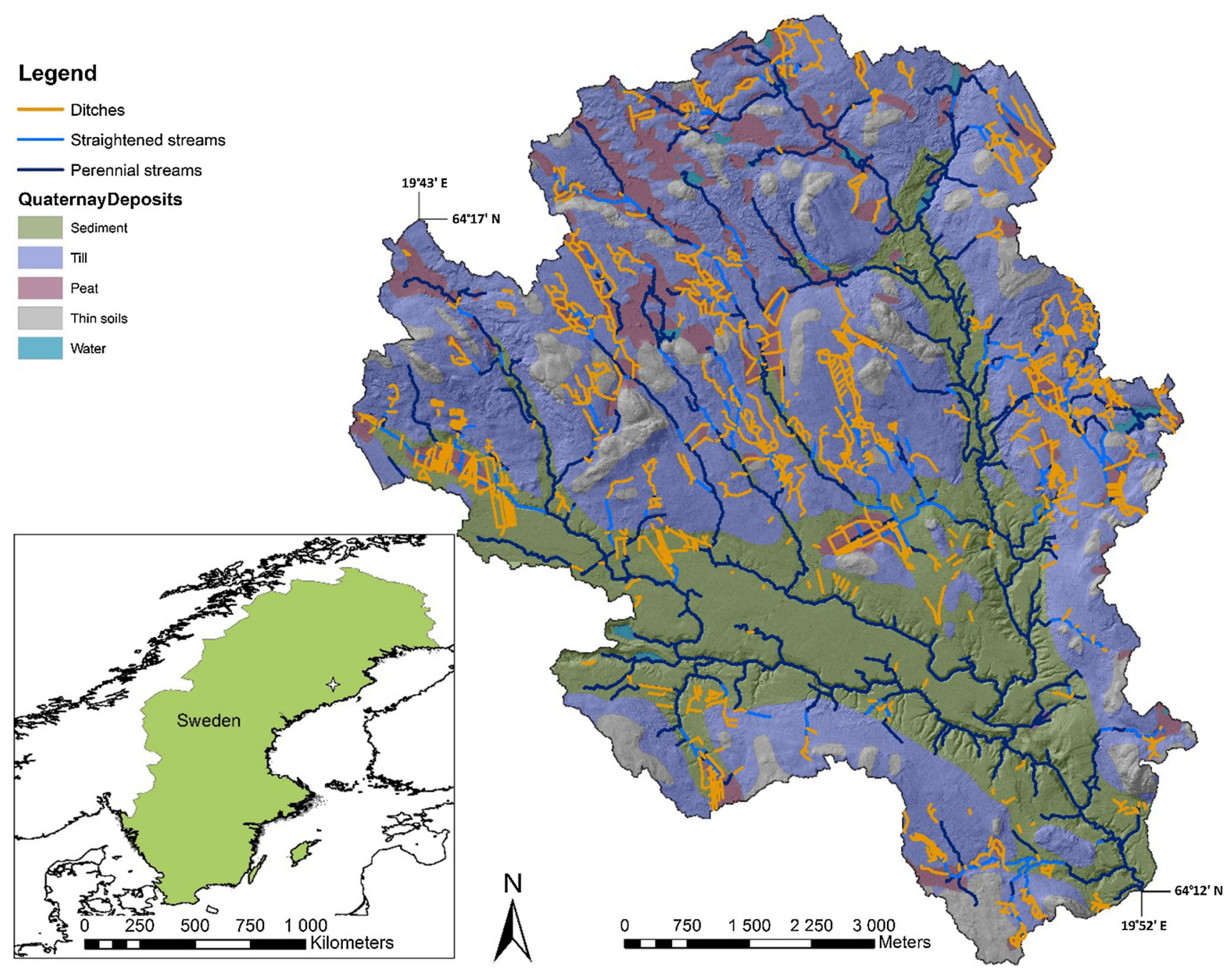

Fig. 1 Location map of study area in northern Sweden. The star on the inset map shows the approximate location of the detailed map. The detailed map displays the outline of the KCS with a hillshade rendition of the topographic relief along with drainage ditches, straightened perennial streams, all perennial streams, and soil types. Latitude and longitude are also noted

probability of ditches to support flowing water, and thereby assess ditch capacity to drain forests: the CA-method and the stream network overlap (SNO)-method.

\section{Catchment area (CA) method}

First, we calculated the CA of each ditch segment using the "add grid values to shapes" tool with the upslope CA as a grid in SAGA GIS (Conrad et al. 2015). To determine which ditches would remain dry at even high flow conditions (i.e. spring flood), we compared the CA's of our ditch segments with the flow initiation threshold areas tested in the field by Ågren et al. (2015). They found that at high flow conditions, the average $\mathrm{CA}$ resulting in flow initiation was 1 ha (range 0.4-4.4 ha) if land was drained by a stream or ditch. Accordingly, if a ditch segment had a CA less than 0.4 ha, it is highly unlikely to support flowing water.

\section{Stream network overlap method (SNO)}

The second method we used to assess the probability of ditches supporting flowing water was to model the spatial extent of the stream network using upslope CA algorithms (Agren et al. 2014) focusing on the flow initiation threshold areas for high flow (1 ha, with a range of 0.4-4.4 ha). We then evaluated the degree of overlap between the modelled stream network and the actual location of ditches using the "intercept" tool in ArcGIS. Ditches that did not overlap with the stream network at high flow, and thus were not modelled to have running water at this time of year when 
water is most likely to be flowing, were considered inactive.

\section{RESULTS}

\section{Ditch characterisation}

There are about $150 \mathrm{~km}$ of ditches within the $68 \mathrm{~km}^{2}$ (6790 ha) KCS (Fig. 1; Table 1). Most ditches were mapped on till soils $(57 \%)$, and the fewest mapped onto thin soils $(1.4 \%$; Table 1$)$. This is in contrast to the density of ditches, where the highest mean densities of ditches were found on deep peat soils $\left(5.88 \mathrm{~km} / \mathrm{km}^{2}\right)$, again with the least dense ditch configurations on thin soils $\left(0.37 \mathrm{~km} / \mathrm{km}^{2}\right.$; Table 1). On average, there are $2.21 \mathrm{~km}$ of ditches per $\mathrm{km}^{2}$ of land (Table 1). Overall, there are $0.84 \mathrm{~km}$ of ditches per $\mathrm{km}$ of perennial stream (10 ha flow initiation point; Table 1), with the highest ratio being in till soils (1.46) and the lowest on sediment (0.28; Table 1$)$. Furthermore, $20 \%$ of the perennial streams have been straightened and were likely ditched at some point in the past.

\section{Upslope CA algorithms}

When using the most conservative CA to initiate flowing water at the KCS (0.4 ha, Agren et al. 2015), our model showed that $25-29 \%$ of all ditches were inactive even during peak flow events, including the spring flood when flows are on average $225 \%$ higher than summer base flows (Karlsen et al. 2016; Table 2; Figs. 2, 3). By comparison, using the average $\mathrm{CA}$ needed to initiate flowing water for ditches at the KCS (1 ha, Agren et al. 2015), 46-51\% of ditches were modelled to be inactive during peak flow events (all ditches with CA sizes of $<0.4$ ha combined with 0.4-1 ha, Table 2). At the high end of the CA needed to initiate flowing water (4.4 ha, Agren et al. 2015), $75-92 \%$ of ditches were modelled to be inactive (all ditches with $\mathrm{CA}$ sizes $<4.4$ ha combined, Table 2 ). When
Table 2 Comparison of the length and total percentage of ditches that are inactive (no flowing water) at high flow within the KCS based on two methods: (1) catchment area (CA) method or (2) stream network overlap (SNO) method, i.e. using a given CA for flow initiation threshold area and determining the degree of overlap with the ditch network. The absolute minimum flow initiation threshold area found in Ågren et al. (2015) during high flow events was 0.4 ha, the mean for locations with drainage ditches was 1 ha, the maximum was 4.4 ha, and perennial streams have CAs of 10 ha

\begin{tabular}{lllll}
\hline Method & $\begin{array}{l}\text { Flow initiation } \\
\text { area (ha) }\end{array}$ & $\begin{array}{l}\text { Inactive } \\
(\mathrm{km})\end{array}$ & $\begin{array}{l}\text { Inactive } \\
(\%)\end{array}$ & $\begin{array}{l}\text { Cumulative \% } \\
\text { inactive }\end{array}$ \\
\hline CA & $<0.4$ & 37 & 25 & 25 \\
SNO & $<0.4$ & 44 & 29 & 29 \\
CA & $0.4-1$ & 39 & 26 & 51 \\
SNO & $0.4-1$ & 26 & 17 & 46 \\
CA & $1-4.4$ & 62 & 41 & 92 \\
SNO & $1-4.4$ & 44 & 29 & 75 \\
CA & $4.4-10$ & 11 & 7 & 100 \\
SNO & $4.4-10$ & 36 & 24 & 100 \\
\hline
\end{tabular}

comparing the two methods, the CA-method and the SNOmethod yielded more similar results at the lower flow initiation threshold areas than at the larger (Table 2). The CAmethod predicted $16 \%$ fewer inactive ditches than the SNO-method at the most conservative flow initiation threshold of 0.4 ha, $50 \%$ more inactive ditches at the lower range (0.4-1 ha) flow initiation thresholds, $41 \%$ more inactive ditches when modelling the upper range (1-4.4 ha), and 69\% fewer inactive ditches when maximum flow initiation thresholds were modelled (4.4-10 ha; Table 2).

\section{DISCUSSION}

We found that there are almost as many ditches as there are perennial streams within the KCS. Furthermore, many perennial streams within the KCS were also identified as straightened, likely to increase their drainage capacity. Indeed, it is noteworthy that in these remote forest

Table 1 Length of ditches and streams in each soil type within the KCS (includes all land cover types). Waterbodies are excluded, thus the catchment area is less than $68 \mathrm{~km}^{2}$

\begin{tabular}{|c|c|c|c|c|c|c|c|c|}
\hline Soil type & $\begin{array}{l}\text { Area } \\
\left(\mathrm{km}^{2}\right)\end{array}$ & $\begin{array}{l}\text { Km of } \\
\text { ditches }\end{array}$ & $\begin{array}{l}\text { Mean }(\min -\max ) \text { density } \\
\text { of ditches }\left(\mathrm{km} / \mathrm{km}^{2}\right)\end{array}$ & $\begin{array}{l}\% \text { of } \\
\text { ditches }\end{array}$ & $\begin{array}{l}\text { Km of straightened } \\
\text { perennial streams }^{\mathrm{a}}\end{array}$ & $\begin{array}{l}\text { Km of all } \\
\text { perennial } \\
\text { streams }^{\mathrm{a}}\end{array}$ & $\begin{array}{l}\% \text { perennial } \\
\text { streams }^{\mathrm{a}} \\
\text { straightened }\end{array}$ & Ditch:stream \\
\hline Till & 34.37 & 84.27 & $2.45(0.01-9.08)$ & 56.59 & 19.61 & 57.57 & 34.06 & 1.46 \\
\hline Peat & 6.34 & 37.28 & $5.88(0.41-28.91)$ & 25.03 & 9.14 & 29.06 & 31.45 & 1.28 \\
\hline Sediment & 20.85 & 25.22 & $1.21(0.10-4.42)$ & 16.94 & 9.5 & 90.19 & 10.53 & 0.28 \\
\hline Thin soils & 5.81 & 2.15 & $0.37(0.08-8.79)$ & 1.44 & 0.47 & 1.27 & 37.01 & 1.69 \\
\hline All & 67.37 & 148.92 & $2.21(0.01-28.91)$ & 100 & 38.72 & 178.08 & 21.74 & 0.84 \\
\hline
\end{tabular}

${ }^{a}$ Perennial straightened streams are cleaned/ditched channels with greater than a 10-ha catchment area (Ågren et al. 2015) 


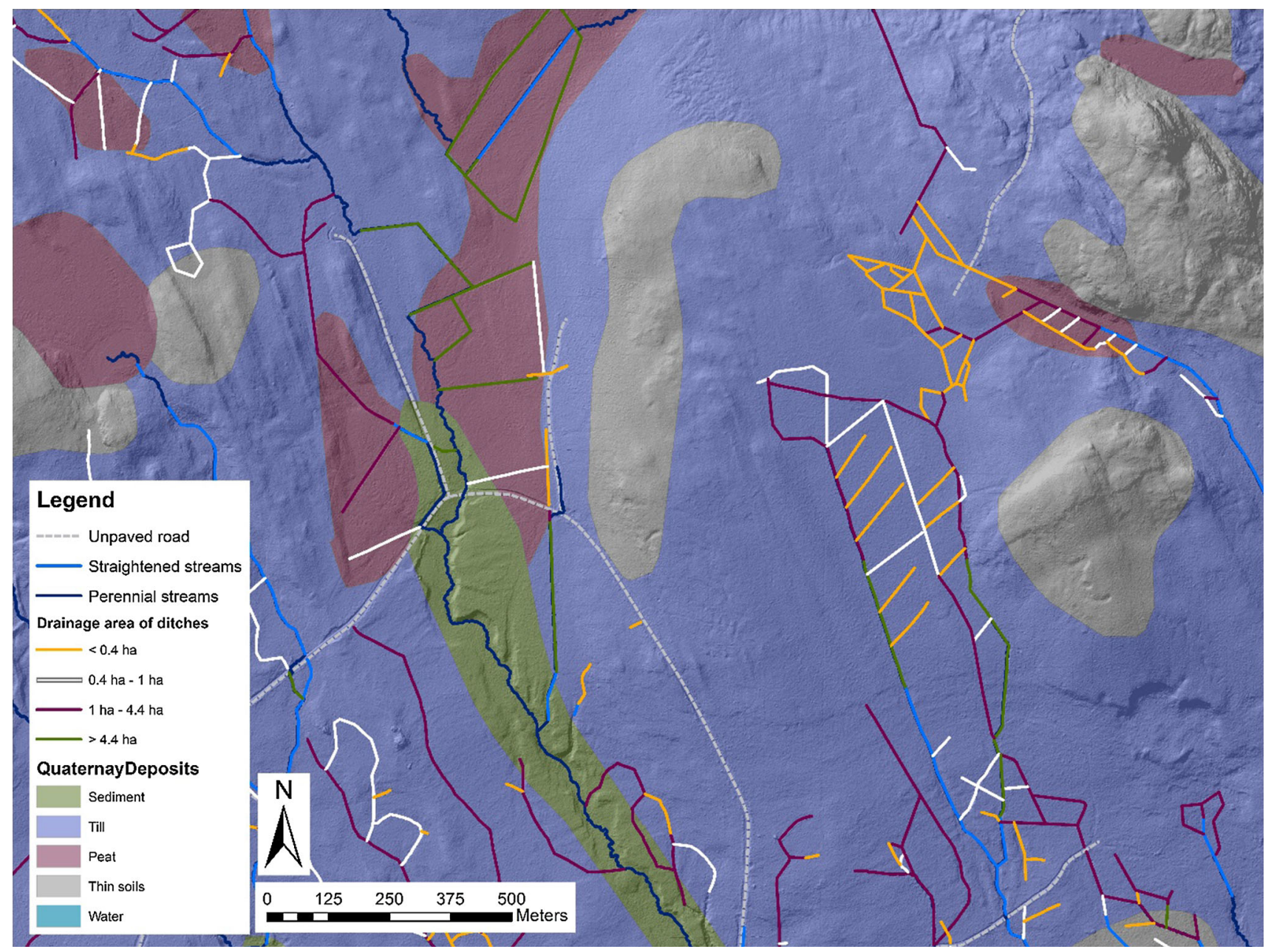

Fig. 2 Drainage ditches and 10 ha streams overlaid on soil type. Ditches are colour coded by their catchment areas (CA): 0.4 ha is the smallest, 1 ha is the mean, and 4.4 ha is the largest flow initiation size during a high flow event based on Ågren et al. (2015). 10 ha streams that have been straightened are also mapped

landscapes-which at first glance appear far less altered than urban and agricultural counterparts-have drainage systems that have been highly modified. It has already been shown that $76 \%$ of the actual stream network is missing on the most current detailed Swedish topographic map $(1: 12,500$; Ågren et al. 2015) and this is a widespread problem often limited by traditional mapping methods that use aerial photography and satellite imagery (Benstead and Leigh 2012). The addition of ditches adds another large component of small stream-like features to the drainage structure of Sweden and likely changes the location of many of the modelled streams. It is difficult to know how many of these ditches were naturally small ephemeral streams activated only occasionally before ditching commenced; regardless, these ditches are now extensions of the stream network and have almost doubled its size.

After this extensive ditching, the stream network geometry is also very different than it was naturally, with dendritic stream network structures transformed to lattices, grids or comb-like systems in the headwaters (Fisher et al. 2004; Figs. 1, 2, 3). Such widespread changes to channel geometry have potentially had dramatic ecological and biogeochemical consequences in these landscapes that merit attention from researchers. For example, the movement of aquatic and riparian organisms may be restricted to corridors (i.e. watercourses) of suitable habitat (Lõhmus et al. 2015). How close these corridors are to each other can influence how frequently overland dispersal occurs and thus shape metacommunity structure in river networks (Brown and Swan 2010; Göthe et al. 2013; Kuglerová et al. 2015), if indeed these ditches provide suitable habitat (Lõhmus et al. 2015). Furthermore, stream network geometry determines the distribution of distances water and solutes travel from points of input on land to the nearest channel (i.e. along terrestrial flowpaths) as well as the time spent in small channels prior to exiting catchments. In this way, major reconfiguration of network structure can affect the overall catchment residence time of 

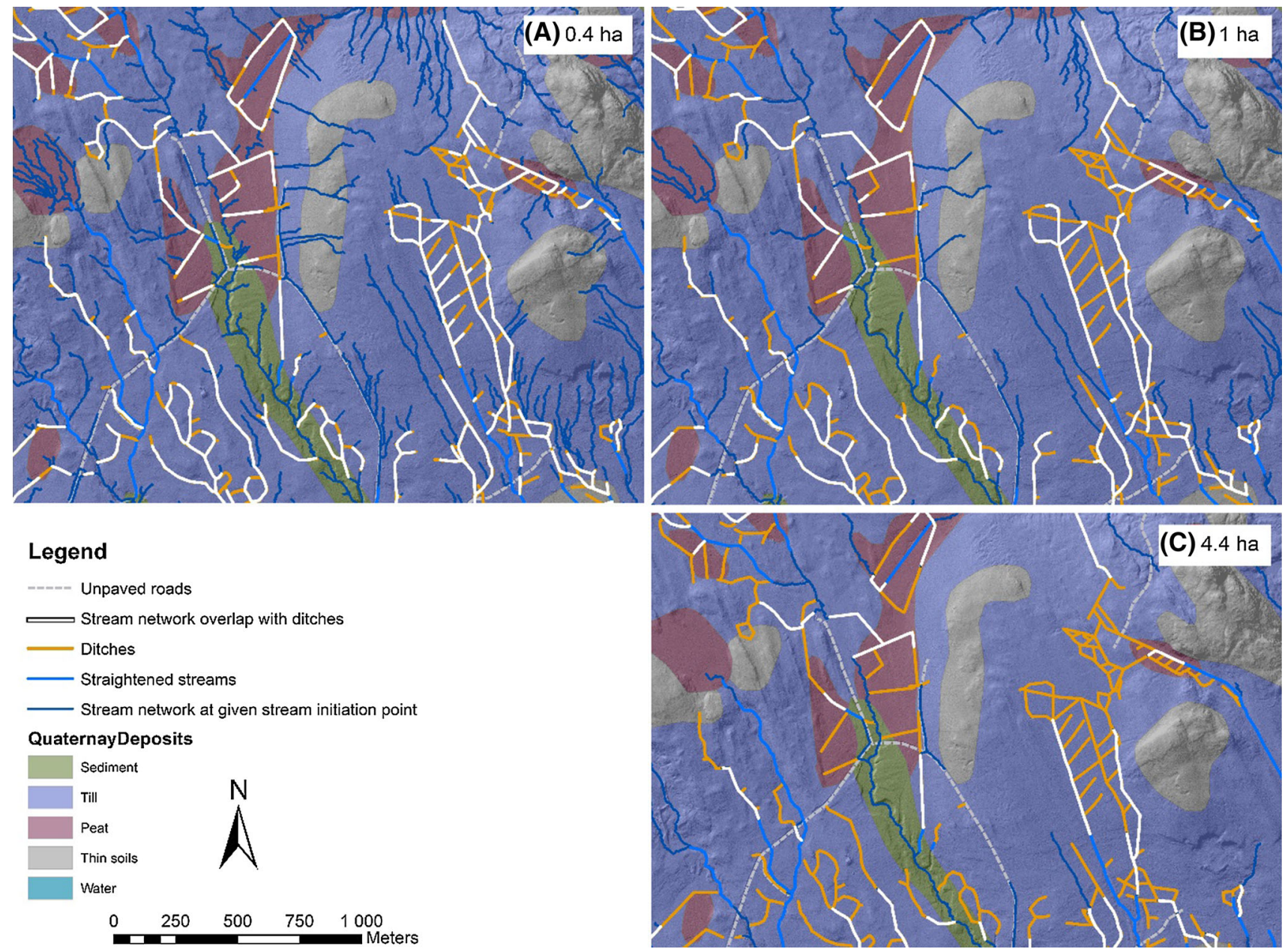

Fig. 3 Map of the stream network overlap (SNO) of forest ditches and a the 0.4 ha stream network, the smallest flow initiation point for high flow events; $\mathbf{b}$ the 1 ha stream network, the mean flow initiation point for high flow events; and $\mathbf{c}$ the 4.4 ha stream network, the maximum flow initiation point for high flow events. If the stream network did not flow in ditches, it was assumed to be dry

solutes and the potential for instream or hyporheic processing within the drainage system (Mallard et al. 2014). Additionally, the number and density of tributary confluences could influence biogeochemical dynamics such as nutrient retention efficiency (Fisher et al. 2004) and sediment distribution and transport (Benda et al. 2004). In a temporal perspective, the presence of a ditch network typically makes hydrographs flashier with higher peak flows and less temporary storage in response to high flow events (Holden et al. 2004) likely resulting in a shorter time window of connectivity between land and water. Hence, ditches have fundamentally altered the hydrological connectivity with major implications for the hydrology, water chemistry, and plant and animal communities that live in and around these watercourses.

In the context of sustainable forest management, disturbance to ditches must be evaluated before considering DNM because this disturbance will be disproportionately transferred downstream (Doyle and Bernhardt 2011).
Furthermore, the effects to surrounding the forest due to the change in hydrology must also be assessed for biodiversity because ditching primarily targets living organisms (notably trees and soil biota) through their limiting factors, i.e. water availability (Lõhmus et al. 2015).

In many countries, decision making for ditching or DNM is almost solely based on site type and estimated timber productivity (considering geographical location; Sikström and Hökkä 2016), but rarely considers hydrological parameters. Although a growing body of literature from Finland is trying to account for the effect of evapotranspiration on drained peatland hydrology (Koivusalo et al. 2006; Sarkkola et al. 2013), they typically do not consider the CAs of specific ditches in their models (e.g. FEMMA; Laurén et al. 2005; Koivusalo et al. 2006). For example, Sarkkola et al. (2013) suggested that no DNM would be necessary in mature stands in central and southern Finland, even if the condition of the ditch network was poor because growing-season precipitation is 
transferred back to the atmosphere by forest evapotranspiration. While in northern Finland, DNM was considered important in low-stocked sites $\left(<100 \mathrm{~m}^{3} \mathrm{ha}^{-1}\right)$ to control drainage conditions because of the low evapotranspiration potential (Sarkkola et al. 2013). Studies that have included CAs are typically those dedicated to evaluating the erosion potential of ditch networks. For example, Holden et al. (2007) showed that channel slope and the upstream CA explained most of the observed variation in erosion occurring across ditched sites. Further, consideration of CA in combination with evapotranspiration modelling using the FEMMA model (Koivusalo et al. 2006) has been successfully used to assess erosion from ditch networks (Haahti et al. 2014) as well as the air-filled porosity of the rooting zone in peatland soils (Haahti et al. 2016). Thus, there is promising research into forest hydrology that may shed light on how we can manage forest stand volumes in order to avoid DNM, but this has not yet been applied at the scale of specific ditches.

\section{Ditches by soil type, evaluating 'thoughtless ditching'}

The density of ditches differed by soil type, presumably because workers targeted soils and areas that were in need of most drainage. However, as hypothesised, there were a number of ditches on soil types that likely do not benefit from added drainage. This 'thoughtless ditching', was located in sedimentary or thin soils that generally have high hydraulic conductivities and drain quickly and deeply (Koch et al. 2011), or are so thin that ditches will likely not help increase tree growth. It may be that workers were paid to dig ditches regardless of their location, and thus, one approach to prioritising DNM would be to map the ditches and compare them to soil types. Doing this, we can recommend that $17 \%$ of ditches be actively or passively restored back to their pre-ditch state (sedimentary + thin soils; Table 1). Furthermore, erosion may more severe in the ditches cut into mineral subsoil than in ditches cut into thick peat (Stenberg et al. 2015); thus, not only should DNM be avoided in these soils due to their quick draining properties, but also because they erode more easily.

Ditches in till soils almost all have overlying peat but are classified as the underlying mineral soil type because the Swedish Geological Society soil map that we used defines peat as $>50.5 \mathrm{~cm}$ (Table 1), therefore even more of these areas would be classified as peatlands in other countries. Areas with $<30 \mathrm{~cm}$ of peat would be called shallow peatlands in Finland, which make up $20.4 \%$ of the all peatlands in Finland, of which $58.3 \%$ have been drained for forestry (Korhonen et al. 2013). Thus, research in Finland is relevant for our study system, with some caution. On these shallow peatlands, initial drainage may be more or less permanent, preventing the re-paludification process (Päivänen and Hånell 2012). Thus, there is likely less potential for DNM needed in these shallow peatlands, but upslope CA algorithms are crucial to be more certain of their potential to drain forest water.

\section{Modelling ditch inactivity, evaluating 'poorly- planned ditches'}

We hypothesised a priori that there are a large number of ditches that, although they may have been dug in soils that could benefit from added drainage (i.e. peat or shallow peat), they do not have sufficient CA to move water regardless of the condition of the ditch (the case of 'poorlyplanned ditching'). We evaluated two methods that use upslope CA algorithms, the CA-method and the SNOmethod for determining if ditches are inactive across the whole KCS, regardless of soil type. The CA-method and the SNO-method yielded more similar results at the lower flow initiation threshold areas than at the larger, likely because the CA-method is an average of the CA over the length of the ditch segment and thus has error built into the measurement. The intervals of the flow initiation areas we report are increasingly wider, and thus, the error from taking an average in the CA-method increases. The SNOmethod is more accurate in that it predicts precisely where flowing water would start within the ditch network. With this in mind, we supported our hypothesis, and at least 25\% of ditches in the KCS likely do not carry flowing water, even during peak flow events $(<0.4$ ha flow initiation CA), and thus serve no contemporary purpose. Given that 0.4 ha is the minimum $\mathrm{CA}$ at which a ditch would be active (Aggren et al. 2015) and that at this threshold the variation among methods was low; any ditches that have $<0.4$ ha CA size would be a conservative threshold for ditch inactivity and thus, a strong candidate for not being maintained. Ditches with between 0.4-1 ha CAs would also be good choices when avoiding DNM because most flow initiation points during high flow events from Ågren et al. (2015) were larger than 1 ha, even when ditches were considered. Thus, between 46 and $51 \%$, when including both the $<0.4$ ha and $0.4-1$ ha CA flow initiation ranges, of ditches within the KCS could be left unmaintained and/or might be candidates for ecological restoration.

One critique of this approach could be that the ditches with small CAs may only be active and important after forest harvest when evapotranspiration is lower, thus raising the water table and hampering tree growth (Sikström and Hökkä 2016). Ågren et al. (2015) tried to model the expansion of groundwater discharge areas after clear-cutting using $\mathrm{K}$-values (saturated hydraulic conductivity of the soil layer in $\mathrm{m} \mathrm{s}^{-1}$ ), but found their use to be difficult to measure and inaccurate. Using experience from recent 
studies from a nearby catchment that underwent a clear-cut harvest, it is likely that flow would, at a maximum, increase by about $30 \%$ during high flow events (Sørensen et al. 2009; Schelker et al. 2013). However, there is high interannual variation in this response, and clear-cutting could have no effect on runoff during some conditions (Schelker et al. 2013). On average, a 1 ha CA was needed to initiate a water flow in ditches during high flow events in Ågren et al. (2015), therefore using the very conservative 0.4 ha that is $60 \%$ lower threshold for flow initiation, even in clear-cut conditions ditches should be inactive. But these assumptions require field testing under different forest ages and across the different soil types to be certain.

\section{Importance and ease of ditch mapping and upslope CA algorithms}

Although the models we used to determine the activity of ditches were developed in the 1970s and 80s (O'Callaghan and Mark 1984), the widespread availability of high-resolution DEMs and free GIS software makes their application less expensive, easier to use and more accurate than what was previously possible. In the past, DEMs were only available at $50 \times 50 \mathrm{~m}$ scale, making upslope CA algorithms too coarse. Now, many countries have nationwide efforts to generate high-resolution LiDAR images. There are currently efforts by the Swedish Forest Agency to map ditches using LiDAR images manually as we did, as well as using image recognition software used previously in agrarian landscapes (Bailly et al. 2008). Their efforts are producing information about the depth and slope of the ditches that could even better refine our models. With these high quality DEMs, combined with free GIS software, one can easily create the high-resolution stream network models and ditch upslope CA algorithms. Thus, this mapping can be done by forest companies, management agencies or landowners, making future management of these small watercourses much more informed.

\section{Soil type (thoughtless ditching) versus upslope CA algorithms (poorly-planned ditching)}

We have discussed two approaches to deciding which ditches should undergo DNM based on: soil type (thoughtless ditching; Table 1) or upslope CA algorithms (poorly-planned ditching; Table 2). There are assumptions and error included in both approaches and forest managers will need to consider which approach works best for them based on data availability and accuracy. For example, soil maps are often readily available for download, but they are usually delineated from aerial photographs and could have substantial error built into them. For upslope CA algorithms, the availability and cost of high-resolution DEMs could prevent accurate mapping of ditches and subsequent modelling. One improvement of the CA-method would be to split the ditches into smaller segments based on the scale at which managers are deciding DNM activities (e.g. 10, 50 or $100 \mathrm{~m}$ lengths) in order to be more accurate as well as make the method more practical for on-the-ground workers.

\section{CONCLUSIONS}

By identifying ditches from new LiDAR-derived DEMs and applying upslope CA algorithms to model their potential to carry flowing water, we have used a novel approach to try to reconcile timber production, water quality and ecosystem conservation (sensu Lõhmus et al. 2015). Before this, there were no published guidelines for DNM oriented toward striking a balance between forest growth and environmental quality. We have taken a first step towards identifying forest drainage ditches that are candidates for not being maintained. First, we located ditches using LiDAR-derived DEMs and found that ditches nearly doubled the size of the stream network (from $178 \mathrm{~km}$ to $327 \mathrm{~km}$ ) within the $\mathrm{KCS}$, a landscape that many would describe as relatively pristine. National LiDAR datasets are being generated throughout Europe and our methods could have widespread application for identifying previously unknown forest ditches. Next, by identifying 'thoughtless ditching', likely done because private forest owners were paid to dig ditches as part of government work programmes, up to $17 \%$ of ditches could be left unmaintained due to being located in well-draining soil types. Finally, using upslope CA algorithms to identify 'poorly-planned ditches', between 25 and $51 \%$ of ditches could be left unmaintained because they do not have enough CA to initiate flow. Future work should focus on field testing these methods to explore how flow initiation thresholds relevant for the KCS apply to areas with different climates, forest ages and soil types as well as incorporate costs (i.e. DNM work and interest rates) and final-cutting criteria (energy wood vs. saw logs) into longterm simulations.

Acknowledgements This study was funded by the Healthy Waters Project (Svenska Forskningsrådet Formas), Skogssällskapet, and the Stiftelsen för Miljöstrategisk Forskning (Mistra) Future Forest programme.

Open Access This article is distributed under the terms of the Creative Commons Attribution 4.0 International License (http:// creativecommons.org/licenses/by/4.0/), which permits unrestricted use, distribution, and reproduction in any medium, provided you give appropriate credit to the original author(s) and the source, provide a link to the Creative Commons license, and indicate if changes were made. 


\section{REFERENCES}

Ågren, A.M., W. Lidberg, and E. Ring. 2015. Mapping temporal dynamics in a forest stream network - implications for riparian forest management. Forests 6: 2982-3001.

Ågren, A.M., W. Lidberg, M. Strömgren, J. Ogilvie, and P.A. Arp. 2014. Evaluating digital terrain indices for soil wetness mapping-a Swedish case study. Hydrology and Earth System Sciences 18: 3623-3634.

Annala, M., H. Mykrä, M. Tolkkinen, T. Kauppila, and T. Muotka. 2014. Are biological communities in naturally unproductive streams resistant to additional anthropogenic stressors? Ecological Applications 24: 1887-1897.

Åström, M., E.-K. Aaltonen, and J. Koivusaari. 2001. Effect of ditching operations on stream-water chemistry in a boreal forested catchment. Science of the Total Environment 279: $117-129$

Bailly, J.S., P. Lagacherie, C. Millier, C. Puech, and P. Kosuth. 2008. Agrarian landscapes linear features detection from LiDAR: application to artificial drainage networks. International Journal of Remote Sensing 29: 3489-3508.

Benda, L., N.L. Poff, D. Miller, T. Dunne, G. Reeves, G. Pess, and M. Pollock. 2004. The Network Dynamics Hypothesis: how channel networks structure riverine habitats. Bioscience 54: 413-427.

Benstead, J.P., and D.S. Leigh. 2012. An expanded role for river networks. Nature Geosci 5: 678-679.

Brown, B.L., and C.M. Swan. 2010. Dendritic network structure constrains metacommunity properties in riverine ecosystems. Journal of Animal Ecology 79: 571-580.

Conrad, O., B. Bechtel, M. Bock, H. Dietrich, E. Fischer, L. Gerlitz, J. Wehberg, V. Wichmann, et al. 2015. System for automated geoscientific analyses (SAGA) v. 2.1.4. Geoscientific Model Development 8: 1991-2007.

Council, F.S. 2010. Swedish FSC standard for forest certification including SLIMF indicators. Sweden: Uppsala.

Doyle, M.W., and E.S. Bernhardt. 2011. What is a stream? Environmental Science and Technology 45: 354-359.

Fisher, S.G., R.A. Sponseller, and J.B. Heffernan. 2004. Horizons in stream biogeochemistry: Flowpaths to progress. Ecology 85: 2369-2379.

Göthe, E., D.G. Angeler, and L. Sandin. 2013. Metacommunity structure in a small boreal stream network. Journal of Animal Ecology 82: 449-458.

Haahti, K., L. Warsta, T. Kokkonen, B.A. Younis, and H. Koivusalo. 2016. Distributed hydrological modeling with channel network flow of a forestry drained peatland site. Water Resources Research 52: 246-263.

Haahti, K., B.A. Younis, L. Stenberg, and H. Koivusalo. 2014. Unsteady flow simulation and erosion assessment in a ditch network of a drained peatland forest catchment in eastern Finland. Water Resources Management 28: 5175-5197.

Hansen, K., V. Kronnäs, T. Zetterberg, M. Setterberg, F. Moldan, P. Pettersson, and J. Munthe. 2013. DiVa: the effects of forest ditch cleaning on discharge, water chemistry, and benthic invertebrates. IVL Swedish Environmental Research Institute Report B2072, 112 pp.

Heikurainen, L. 1957. Changes in depth and top width of forest ditches and the maintaining of their repair. Acta Forestalia Fennica 65: 1-45 (In Finnish, English summary).

Holden, J., P.J. Chapman, and J.C. Labadz. 2004. Artificial drainage of peatlands: hydrological and hydrochemical process and wetland restoration. Progress in Physical Geography 28: 95-123.

Holden, J., M. Gascoign, and N.R. Bosanko. 2007. Erosion and natural revegetation associated with surface land drains in upland peatlands. Earth Surface Processes and Landforms 32: $1547-1557$.

Hynninen, A., S. Sarkkola, A. Lauren, H. Koivusalo, and M. Nieminen. 2011. Capacity of riparian buffer areas to reduce ammonium export originating from ditch network maintenance areas in peatlands drained for forestry. Boreal Environment Research 16: 430-440.

Jencso, K.G., and B.L. McGlynn. 2011. Hierarchical controls on runoff generation: Topographically driven hydrologic connectivity, geology, and vegetation. Water Resources Research 47: W11527. doi:10.1029/2011WR010666.

Joensuu, S., E. Ahti, and M. Vuollekoski. 2002. Effects of ditch network maintenance on the chemistry of run-off water from peatland forests. Scandinavian Journal of Forest Research 17: 238-247.

Karlsen, R.H., T. Grabs, K. Bishop, I. Buffam, H. Laudon, and J. Seibert. 2016. Landscape controls on spatiotemporal discharge variability in a boreal catchment. Water Resources Research 52: 6541-6556.

Koch, K., A. Kemna, J. Irving, and K. Holliger. 2011. Impact of changes in grain size and pore space on the hydraulic conductivity and spectral induced polarization response of sand. Hydrology and Earth Systems Sciences 15: 1785-1794.

Koivusalo, H., E. Ahti, A. Laurén, T. Kokkonen, T. Karvonen, R. Nevalainen, and L. Finér. 2008. Impacts of ditch cleaning on hydrological processes in a drained peatland forest. Hydrology and Earth Systems Sciences 12: 1211-1227.

Koivusalo, H., T. Kokkonen, A. Laurén, M. Ahtiainen, T. Karvonen, H. Mannerkoski, S. Penttinen, P. Seuna, et al. 2006. Parameterisation and application of a hillslope hydrological model to assess impacts of a forest clear-cutting on runoff generation. Environmental Modelling \& Software 21: 1324-1339.

Korhonen, K.T., A. Ihalainen, H. Viiri, J. Heikkinen, H.M. Henttonen, J.-P. Hotanen, H. Mäkelä, S. Nevalainen, and J. Pitkänen. 2013. Finland's forests 2004-2008 and their development 1921-2008. Metsätieteen aikakauskirja 3: 269-608 (In Finnish).

Kuglerová, L., R. Jansson, R.A. Sponseller, H. Laudon, and B. MalmRenöfält. 2015. Local and regional processes determine plant species richness in a river-network metacommunity. Ecology 96: 381-391.

Kuglerová, L., A. Ågren, R. Jansson, and H. Laudon. 2014. Towards optimizing riparian buffer zones: Ecological and biogeochemical implications for forest management. Forest Ecology and Management 334: 74-84.

Laudon, H., L. Kuglerová, R.A. Sponseller, M. Futter, A. Nordin, K. Bishop, T. Lundmark, G. Egnell, et al. 2016. The role of biogeochemical hotspots, landscape heterogeneity, and hydrological connectivity for minimizing forestry effects on water quality. Ambio 45: 152-162. doi:10.1007/s13280-015-0751-8.

Laudon, H., I. Taberman, A. Ågren, M. Futter, M. OttossonLöfvenius, and K. Bishop. 2013. The Krycklan Catchment Study-A flagship infrastructure for hydrology, biogeochemistry, and climate research in the boreal landscape. Water Resources Research 49: 7154-7158.

Laurén, A., L. Finér, H. Koivusalo, T. Kokkonen, T. Karvonen, S. Kellomäki, H. Mannerkoski, and M. Ahtiainen. 2005. Water and nitrogen processes along a typical water flowpath and streamwater exports from a forested catchment and changes after clearcutting: a modelling study. Hydrology and Earth Systems Sciences 9: 657-674.

Lavoie, M., D. Pare, N. Fenton, A. Groot, and K. Taylor. 2005. Paludification and management of forested peatlands in Canada: A literature review. Environmental Reviews 13: 21-50.

Lepistö, A., L. Andersson, B. Arheimer, and K. Sundblad. 1995. Influence of catchment characteristics, forestry activities and 
deposition on nitrogen export from small forested catchments. Water, Air, and Soil pollution 84: 81-102.

Lindsay, J.B. 2016. Efficient hybrid breaching-filling sink removal methods for flow path enforcement in digital elevation models. Hydrological Processes 30: 846-857.

Lõhmus, A., L. Remm, and R. Rannap. 2015. Just a ditch in forest? Reconsidering draining in the context of sustainable forest management. BioScience 65: 1066-1076.

Lundberg, G. 1914. Handbook for forest ditching. Stockholm: C.E. Fritzes bokförlags aktiebolag (In Swedish).

Mallard, J., B. McGlynn, and T. Covino. 2014. Lateral inflows, stream-groundwater exchange, and network geometry influence stream water composition. Water Resources Research 50: 4603-4623.

Manninen, P. 1998. Effects of forestry ditch cleaning and supplementary ditching on water quality. Boreal Environment Research 3: 23-32.

O'Callaghan, J.F., and D.M. Mark. 1984. The extraction of drainage networks from digital elevation data. Computer Vision, Graphics, and Image Processing 28: 323-344.

Paavilainen, E., and J. Päivänen. 1995. Peatland forestry ecology and principles. New York: Springer.

Painter, R.B., K. Blyth, J.C. Mosedale, and M. Kelly. 1974. The effect of afforestation on erosion processes and sediment yield. IAHS Publication 113: 62-67.

Prevost, M., A.P. Plamondon, and P. Belleau. 1999. Effects of drainage of a forested peatland on water quality and quantity. Journal of Hydrology 214: 130-143.

Price, J.S., A.L. Heathwaite, and A.J. Baird. 2003. Hydrological processes in abandoned and restored peatlands: an overview of management approaches. Wetlands Ecology and Management 11: $65-83$.

Päivänen, J., and B. Hånell. 2012. Peatland ecology and forestry-a sound approach. Helsinki: University of Helsinki Department of Forest Sciences Publications 3.

Rawls, W., L. Ahuja, D. Brakensiek, and A. Shirmohammadi. 1993. Infiltration and soil water movement. In Handbook of hydrology, ed. D. Maidment, 5-7. New York: McGraw-Hill.

Rodhe, A., and J. Seibert. 1999. Wetland occurrence in relation to topography: a test of topographic indices as moisture indicators. Agricultural and Forest Meteorology 98: 325-340.

Rydin, H., and J. Jeglum. 2009. The biology of peatlands. Oxford: Oxford University Press.

Sarkkola, S., M. Nieminen, H. Koivusalo, A. Laurén, E. Ahti, S. Launiainen, E. Nikinmaa, H. Marttila, et al. 2013. Domination of growing-season evapotranspiration over runoff makes ditch network maintenance in mature peatland forests questionable. Mires and Peat 11: 1-11.

Schelker, J., L. Kuglerová, K. Eklöf, K. Bishop, and H. Laudon. 2013. Hydrological effects of clear-cutting in a boreal forest-snowpack dynamics, snowmelt and streamflow responses. Journal of Hydrology 484: 105-114.

Sikström, U., and H. Hökkä. 2016. Interactions between soil water conditions and forest stands in boreal forests with implications for ditch network maintenance. Silva Fennica 50. doi:10.14214/ sf.1416.

Silins, U., and R.L. Rothwell. 1998. Forest peatland drainage and subsidence affect soil water retention and transport properties in an Alberta peatland. Soil Science Society of America Journal 62: 1048-1056.

Stenberg, L., T. Tuukkanen, L. Finér, H. Marttila, S. Piirainen, B. Kløve, and H. Koivusalo. 2015. Ditch erosion processes and sediment transport in a drained peatland forest. Ecological Engineering 75: 421-433.

Sørensen, R., E. Ring, M. Meili, L. Högbom, J. Seibert, T. Grabs, H. Laudon, and K. Bishop. 2009. Forest harvest increases runoff most during low flows in two boreal streams. Ambio 38: 357-363. doi:10.1579/0044-7447-38.7.357.

\section{AUTHOR BIOGRAPHIES}

Eliza Maher Hasselquist $(\bowtie)$ is a postdoctoral researcher who focuses on how historic forestry practices have affected the hydrogeomorphology and ecology of mid-size streams down to the "least fantastic of our water systems - the ditch" (Jakobsson 2013).

Address: Department of Forest Ecology and Management, Swedish University of Agricultural Sciences (SLU), Skogsmarksgränd, 90183 Umeå, Sweden.

e-mail: eliza.hasselquist@gmail.com

William Lidberg is a $\mathrm{PhD}$ student studying how upslope catchment area algorithms can be used for determining the location of waterways throughout Sweden, with the goal of improving forest management for water quality protection.

Address: Department of Forest Ecology and Management, Swedish University of Agricultural Sciences (SLU), Skogsmarksgränd, 90183 Umeå, Sweden.

e-mail: william.lidberg@slu.se

Ryan A. Sponseller is an Associate Professor in Ecosystem Ecology. His research focuses on the ecology and biogeochemistry of streams, rivers, and watersheds.

Address: Department of Ecology and Environmental Science, Umeå University, 90187 Umeå, Sweden.

e-mail: ryan.sponseller@umu.se

Anneli Ågren is an Associate Professor in Aquatic Landscape Analysis and her research focuses on linking water quality and the terrestrial boreal forest ecosystem. She primarily uses digital terrain indices to map the connectivity of different landscapes to streams.

Address: Department of Forest Ecology and Management, Swedish University of Agricultural Sciences (SLU), Skogsmarksgränd, 90183 Umeå, Sweden.

e-mail: anneli.agren@slu.se

Hjalmar Laudon is a Professor of Forest Landscape Biogeochemistry. His research interests are primarily related to hydrology and biogeochemistry in the forested landscape and questions related to the role of connectivity, scaling, forestry impact, and climate change. Address: Department of Forest Ecology and Management, Swedish University of Agricultural Sciences (SLU), Skogsmarksgränd, 90183 Umeå, Sweden. e-mail: hjalmar.laudon@slu.se 